OPEN ACCESS

Edited by:

Ingrid Sivesind Mehlum, National Institute of Occupational Health, Norway

Reviewed by: Victor C. W. Hoe,

University of Malaya, Malaysia Caterina Ledda,

University of Catania, Italy

*Correspondence:

Esteban Agulló-Tomás estomas@uniovi.es

Specialty section:

This article was submitted to Occupational Health and Safety,

a section of the journal

Frontiers in Public Health

Received: 12 January 2020 Accepted: 15 September 2020 Published: 09 October 2020

Citation:

Menéndez-Espina S, Llosa JA Agulló-Tomás E, Rodríguez-Suárez J, Sáiz-Villar R, Lasheras-Díez HF, De Witte H and Boada-Grau J (2020) The Influence of Gender Inequality in the

Development of Job Insecurity:

Differences Between Women and Men. Front. Public Health 8:526162. doi: 10.3389/fpubh.2020.526162

\section{The Influence of Gender Inequality in the Development of Job Insecurity: Differences Between Women and Men}

\author{
Sara Menéndez-Espina ${ }^{1}$, Jose Antonio Llosa ${ }^{2}$, Esteban Agulló-Tomás ${ }^{1 *}$, \\ Julio Rodríguez-Suárez ${ }^{1}$, Rosana Sáiz-Villar ${ }^{1}$, Héctor Félix Lasheras-Díez ${ }^{1}$, \\ Hans De Witte ${ }^{3,4}$ and Joan Boada-Grau ${ }^{5}$ \\ ${ }^{1}$ Department of Psychology, Oviedo University, Oviedo, Spain, ${ }^{2}$ Department of Health Sciences, Universidad Internacional de \\ La Rioja (UNIR), Logroño, Spain, ${ }^{3}$ Research Unit Occupational \& Organizational Psychology and Professional Learning (O2L) \\ KU Leuven, Leuven, Belgium, ${ }^{4}$ Optentia Research Focus Area, North-West University, Vanderbilipark, South Africa, \\ ${ }^{5}$ Department of Psychology, Rovira i Virgili University, Tarragona, Spain
}

Job insecurity is an indicator of precarious work that refers to the fear of losing one's job. It is a relevant source of stress, with negative consequences on people's mental health. The main objective and contribution of this study is to identify how gender inequality and job insecurity are related, responding to the lack of consensus found in scientific literature in this field of study. To do so, a predictive study of job insecurity, broken down by gender, is developed, considering sociodemographic and labor variables as antecedents. The sample included 1,005 employees (420 men and 585 women) aged between 18 and 65, and a linear regression was conducted for each group. Results show that women perceive greater insecurity under precarious working conditions (temporary work, informal work, salary cuts, tenure), whereas in the case of men variables related to their professional careers (job category, education) and household incomes were relevant predictors. It is concluded that job insecurity affects both gender groups, but the conditions in which this perception grows are significantly impacted by gender inequality. These findings will allow for holistic and effective actions to decrease the effects of precarious work.

Keywords: job insecurity, temporary work, gender perspective, non-standard work, occupational health

\section{INTRODUCTION}

Perceived job insecurity is understood, in its original formulation, as "the perceived powerlessness to maintain the desired continuity in a threatened job situation" (1). It is also defined as "one's expectations about continuity in a job situation" (2) or "the general concern of employees in terms of the future continuity in a desired job situation" (3). It is a field of study resulting from research into work-related stress and its harmful impact on health, at a time when some of the dimensions of the welfare state are being questioned. The origin of the study of job insecurity coincides with the 1973 oil crisis and the expansion of liberal policies fostered by Margaret Thatcher and the other conservative governments during the 1980s. From then on, globalization is consolidated giving way to what Bauman (4) describes as "liquid employment," where a decline of labor and 
social rights of the Keynesian welfare system occurred. This system emerged as a social pact after World War II and was based on the possibility of a full employment paradigm, where access to labor market implied access to the system of social protections. The result of this change is a type of weak, flexible and uprooted (5) and, ultimately, precarious $(6,7)$ employment. This evolution that summarizes the trend over the last quarter of the twentieth century is aggravated during the global economic crisis at the turn of the new millennium. Beck (8) states that, in a framework in which employment tends toward a progressive deregulation of rules, there is greater interest in analyzing precarious conditions by studying the perceptions of employees and not only through the formal features of labor relations. Thus, over recent years there has been increasingly more interest in studying job insecurity (9). Current precarious labor relations and conditions are based on flexibility and instability, and perceived job insecurity is understood, in this article, as a highly relevant tool to assess the effects and experience of flexible employment (10). In other words, it connects the social reality of work and the personal experience of that reality. Therefore, job insecurity is a subjective (1), involuntary and uncontrollable (11) process that anticipates the loss (2) of a labor situation that one wishes to maintain (3).

The avenues of research on perceived job insecurity consider this phenomenon as a stressor, assuming that flexible and deregulated labor relations and conditions always imply some discontent. Thus, subjective job insecurity has been associated with negative and dysfunctional effects on employees' well-being (12). Specifically, it has been observed effects on general mental health (13), depression (14), anxiety (15), and even in relation to suicidal ideation (16), as well as to physical well-being (17) or specific syndromes related to physical health, as for example heart conditions $(18,19)$. The study of job insecurity has a long history in Anglo-Saxon contexts, and it is still a highly relevant and current topic (20). Job insecurity is a dynamic construct in terms of its development, related to the economic and social circumstances of the country or the region subject to study. Thus, Lübke and Erlinghagen (21) show the differences in perceived job insecurity in the different countries, according to the situation of the labor market in the past, the current economic situation and the welfare policies implemented. Likewise, recent literature reviews have confirmed this fact, finding that as unemployment rates grow, there are higher levels of job insecurity $(22,23)$.

In addition to the socioeconomic context that justifies and urges further research on job insecurity, some aspects of this phenomenon still must be identified, and others have to be studied in greater depth. One of them refers to the situation of women. More specifically, the way in which gender inequality, historically generated in the employment scenario $(24,25)$ is related to job insecurity. There is extensive empirical evidence showing differences between men's and women's work based on discrimination against women (26-29), which are repeated and increase over the years $(25,30,31)$. This fact is translated in specific phenomena such as the gender pay gap, occupational segregation, higher rates of part-time and informal employment in women, as well as a greater burden of care work $(25,27)$. However, we believe that it is also necessary to know its implication in the characteristics and development of job insecurity.

The study of different aspects of job insecurity had already been presented previously from a gender perspective (32-36). However, there is no consensus in the scientific literature regarding the relationship established between job insecurity and gender. It is difficult to answer the question of which group scores higher in this variable, and which is more affected by the consequences. Traditionally, this experience was considered to occur to a greater extent among men (37). This conception responds to the model of man as the breadwinner (38). In households where the woman is the main breadwinner, no differences with men are found (39). Other studies, in contrast, have found a greater degree of job insecurity among women $(12,40,41)$. These results are to be expected because women usually undertake more flexible, temporary and parttime jobs $(25,29,42)$. A third view, wider spread and embraced, considers that there are no gender differences in relation to job insecurity, understanding this as a source of stress both in men and in women $(36,43,44)$. Likewise, Gaunt and Benjamin (33) find that the differences derive from whether women with paid jobs have a more traditional or household work-oriented ideology, or on the contrary a more egalitarian ideology, namely, more focused on their professional careers. Thus, women belonging to the first group suffer less job insecurity than women in the second group. Anyhow, the trend is to focus these studies on male-female couple households, although today there is a wider variety of household models. Keim et al. (22) take a more global approach, establishing a relationship between increased job insecurity scores in men and women and the rise of unemployment rates in the country of residence, as is the case of Spain. Thus, the scenario of the study on job insecurity in men and women is characterized by a great disparity of results, confirming the need to design research studies based and developed in agreement with the criteria and recommendations of the gender perspective (45). Social inequality between men and women occurs in all life domains, but it is in employment where it is more obvious and concerning (25). In this context, we think that job insecurity must necessarily be a phenomenon that is affected by this inequality. Therefore, this research proposes a new approach to study gender differences in job insecurity: we want to test that there are no differences between men and women as a general measure, but they exist when we analyse the objective background that facilitates its appearance.

H1: There is no difference between the general score for job insecurity in Men and women

Several studies have looked into predictors or precursors of job insecurity, including gender $(9,22,46-48)$. Out of all classifications of this type of predictive variables, our benchmark has been Probst and Lavaysse (23). We chose two types of factors: first, demographic variables, and, second, variables related to labor conditions. Both are under the umbrella of what these authors call individual and objective factors. We understand that these individual and objective factors place certain population groups in a weaker labor position, facilitating the loss of employment. Previous research has found a greater perception 
of job insecurity (49). Urbanaviciute et al. (50) refer to this weak labor position as a precariousness profile.

The demographic set includes variables such as age or academic education, as well as certain household characteristics like having children and household income. In terms of age, studies found that job insecurity increases with the passing of time (48). However, other authors found no linear relationship between both variables (51). Fullerton and Wallace (52) even describe a curvilinear relationship. This means that the youngest and oldest employees have less fear of losing their jobs. However, studies conducted after the 2008 economic crisis seem to refute this idea. According to Keim et al. (22), young people experience most insecurity, and this relationship is aggravated at times with higher unemployment rates. In the same line, Buonocore et al. (26) have identified specific generational differences: people born between 1980 and 1994 tended to perceive higher levels of job insecurity than previous generational groups at the time of the study, carried out in 2010. In terms of education, job insecurity has traditionally been related to a lower educational level (53), although more recent studies show an inverted relationship $(54,55)$. Thus, Kinnunen et al. (56) and Keim et al. (22) state that it also depends on macroeconomic variables, so that when there are high unemployment rates, people with higher qualifications have the highest job insecurity levels. In contrast, when the job offer is sufficient, having higher education levels dampens job insecurity. On the other hand, householdrelated variables have also been analyzed as possible predictors of perceived job insecurity. The studies by Näswall and De Witte (48) and Richteret al. (35) compare the impact of having dependent children in different countries, without concluding that it is a predictor of job insecurity. A similar study by Muñoz de Bustillo and de Pedraza (47), only establishes a significant positive relationship between having dependent children and the development of subjective job insecurity in the case of some European Mediterranean culture regions. Another variable of interest is the family's economic situation, related to the main breadwinner $(35,36)$, and the existence of a spouse who also works and contributes to the household income. In this respect, Mauno and Kinnunen (57) observe, in man-woman couples with two salaries, that the concern for the economic situation of one of the spouses generates greater job insecurity in the other one.

H2: Job insecurity increases in a more vulnerable socioeconomic context, such as (a) lower household income, (b) having children, and (c) a lower level of education.

The second set includes predictive variables related to labor conditions. Keim et al. (22) and Shoss (9) have identified these factors. Temporary and part-time contracts increase job insecurity $(48,58,59)$. Moreover, a longer time spent in a company is associated with less job insecurity (21). The same applies to professional categories: white collar workers or with a higher qualifications perceive less insecurity than blue collar workers (60). Changes in the organization, such as reorganizations or salary restructuring, salary cuts or staff reductions also increase insecurity $(9,23)$. Other type of employees that is highly susceptible to experience job insecurity are self-employed workers (61). We believe that they require more in-depth studies. This was also highlighted by Shoss (9), given the increase in self-employed workers in recent years (e.g., Eurostat 2017 data). In addition, informal work, without contractual relationships, is presented as an important form of precariousness with serious implications for insecurity (62) and health (63).

H3: The level of job insecurity increases in the case of being in a weak Labor position, such as (a) informal work, (b) temporary contracts, (c) part-time work and (d) having suffered a salary cut in the last year.

H4: In a stronger Labor position, such as (a) a longer tenure and (b) a white-collar job category, the job insecurity decreases.

\section{THIS STUDY}

In this study we incorporate social and contextual factors as precursors of job insecurity instead of intrapsychic variables. The reason is that these factors do not consider the individual to be the origin of the insecurity, but rather the surrounding social circumstances. We want to provide evidence on the weight that this type of variables has on the perception of job insecurity. To do so, our first objective is to analyse different socioeconomic factors that affect to job insecurity. A second objective is to incorporate the gender perspective to previous knowledge in this area. This allows us to propose different levels of organizational and institutional interventions, showing that we are facing a psychosocial phenomenon that affects workers. So, the research question asked is: do the demographic and labor factors related to job insecurity have a different effect on women and men? This question is based on the weaker position that women typically occupy in the labor market, along with other factors that are also related to greater difficulty in accessing employment. More recent scientific literature concludes that job insecurity is experienced equally by men and women, although there is no clear consensus. The reasons for this could be the limited number of genderbased studies on the topic that consider the unequal conditions of female work.

\section{MATERIALS AND METHODS}

\section{Participants}

Quota and convenience sampling were conducted. To this end, the target group for the study was defined as men and women between 18 and 65 years of age, who were working and resided in Spain. Then, volunteers were sought to complete the questionnaire online during a period of 6 months. Once we had a sufficient number of participants, the well-completed questionnaires and those that answered the requested profile were filtered. The sample obtained comprises 1,005 individuals, living in different Spanish regions: 420 men and 585 women, with an average age of 36.03 years ( $\mathrm{SD}=12.24)$. The participants' characteristics are summed up in Table 1.

\section{Instruments}

Version JIS-8 of the Job Insecurity Scale (64), validated in the Spanish population by Llosa et al. (10) has been used to measure Job Insecurity. The original scale shows a realiability above 0.80 with the Conbrach's alpha test; in the Spanish validation a index of 
TABLE 1 | Means, standard deviations and frequencies of the socio-economic and labor variables.

\begin{tabular}{|c|c|c|c|}
\hline Variables & Total & Men & Women \\
\hline Age & $36.03(12.24)$ & $36.66(13.21)$ & $35.57(11.49)$ \\
\hline $\begin{array}{l}\text { Household income } \\
\text { (Euros/month) }\end{array}$ & $\begin{array}{l}2120.68 \\
(1296.35)\end{array}$ & $\begin{array}{l}2404.19 \\
(1449.35)\end{array}$ & $\begin{array}{c}1918.47 \\
(1133.95)\end{array}$ \\
\hline Number of children & $0.38(0.69)$ & $0.31(0.65)$ & $0.42(0.71)$ \\
\hline Tenure (months) & $104.48(146.46)$ & $119.6(150.79)$ & $97.77(142.06)$ \\
\hline \multicolumn{4}{|l|}{ Education } \\
\hline University education $=0$ & 332 (33\%) & 169 (50.9\%) & $163(49.1 \%)$ \\
\hline No university education $=1$ & $673(67 \%)$ & 251 (37.3\%) & $422(62.7 \%)$ \\
\hline \multicolumn{4}{|l|}{ Job category } \\
\hline White collar $=0$ & 198 (19.7\%) & 100 (50.5\%) & 98 (49.5\%) \\
\hline Blue collar = 1 & 807 (80.3\%) & 320 (39.7\%) & 487 (60.3\%) \\
\hline \multicolumn{4}{|l|}{ Temporary work } \\
\hline Temporary contract $=1$ & 568 (56.5\%) & 207 (36.4\%) & $361(63.6 \%)$ \\
\hline Open-ended contract $=0$ & 437 (43.5\%) & $213(48.7 \%)$ & 224 (51.3\%) \\
\hline \multicolumn{4}{|l|}{ Part-time Work } \\
\hline Part-time day $=1$ & 270 (26.9\%) & 93 (34.4\%) & 177 (65.6\%) \\
\hline Full day $=0$ & 735 (73.1\%) & 327 (44.5\%) & 408 (55.5\%) \\
\hline \multicolumn{4}{|l|}{ Informal work } \\
\hline With contract $=0$ & 897 (89.3\%) & 380 (42.4\%) & 517 (57.6\%) \\
\hline Without contract $=1$ & 108 (10.7\%) & $40(37 \%)$ & 68 (63\%) \\
\hline \multicolumn{4}{|l|}{ Self-employment } \\
\hline Self-employed = 1 & $101(10 \%)$ & 55 (54.5\%) & $46(45.5 \%)$ \\
\hline Employee $=0$ & 904 (90\%) & $365(40.4 \%)$ & 539 (59.6\%) \\
\hline \multicolumn{4}{|l|}{ Salary cut } \\
\hline Cut in last year $=1$ & 199 (19.8\%) & $73(36.7 \%)$ & $126(63.3 \%)$ \\
\hline No cut in last year $=0$ & 780 (77.6\%) & 338 (43.3\%) & 442 (56.7\%) \\
\hline
\end{tabular}

Standard deviation and percentages on brackets. $N($ men $)=420 ; N($ women $)=585$; "net income; Confidence interval: $95 \%$.

$\alpha=0.90$ was obtained. The scale comprises 8 items on a 5 -point Likert scale format. It offers a global score on Job Insecurity, as well as for two dimensions: cognitive and affective. The range of the sum scores is from 8 to 40 .

The coding of socio-demographic variables and working conditions-related variables have been taken from European surveys drawn up by Eurofound, such as the European Working Conditions Survey (EWCS) 2010 version, European Social Survey (ESS), version number 6, and the International Standard Classification of Occupations (ISCO-08). The Age, Household Income and Tenure variables are numerical. The other variables have been transformed into dichotomic variables or dummy variables (65), and take the following values: informal work ( 0 with contract, 1 without contract); Temporary Work (1 temporary contract, 0 open-ended contract), Parttime work (1 part-time day, 0 full day); Job Category (0 white collar, 1 blue collar); Self-employment (1 self-employed worker, 0 third-party worker), and Education ( 0 with university studies, 1 without university studies). We also added a variable related to changes in the company, which is Salary Cut (1 salary cuts in last year, 0 no cuts in salary in last year).
TABLE 2 | Two-Sample $t$-Test for Job Insecurity in women and men.

\begin{tabular}{|c|c|c|c|c|c|c|}
\hline & & \multicolumn{2}{|c|}{ Levene test } & \multicolumn{3}{|c|}{$t$-test } \\
\hline \multicolumn{2}{|c|}{ Means (SD) } & $\mathbf{F}$ & $\mathbf{P}$ & $t$ & df & $\boldsymbol{P}$ \\
\hline Men & 19.5 (7.17) & 0.635 & 0.426 & -5.420 & 1,003 & 0.000 \\
\hline Women & 21.9 (6.94) & & & & & \\
\hline
\end{tabular}

\section{Procedure}

The respondents completed a self-administered questionnaire with all variables. All participants were informed of the objectives, characteristics, and procedures of the study, and signed the informed consent prior to completing the questionnaire. This research follows the requirements and protocols of the Ethics Committee of Oviedo University, where it was performed, as well as all the ethical demands and recommendations included in section 8 of the Ethical Principles of Psychologists and Code of Conduct of the APA (66).

\section{Data Analysis}

First, a descriptive analysis of the data was conducted to determine the sample characteristics and the average scores on the JIS- 8 scale. Then, a Two-Sample T-Test was carried out to compare the score in job insecurity between women and men.

A stepwise linear regression analysis was conducted separately for men and women. Socio-economic type variables (Age, Education, Household Income, and Number of Children) were used, as well as labor type variables (Informal Work, Temporary Work, Part-time Work, Tenure, Job Category, Salary Cut and Self-employment). A $P$-value of 0.05 was chosen as the significance level in the analysis.

\section{RESULTS}

The results of the Two-Sample T-Test are displayed in Table 2. In general, women show a higher average score in Job Insecurity (M $=21.9 ; \mathrm{SD}=6.94)$ than $\operatorname{men}(\mathrm{M}=19.5 ; \mathrm{SD}=7.17 ; t=-5.420$; $P<0.001)$.

Table 3 includes the correlations between the dependent variable (Job Insecurity) and the numerical predictors, both for men and for women. In males, Job Insecurity statistically significantly and positively correlates with Education $(r=0.115)$, Temporary Work $(r=0.329)$, and Salary Cut $(r=0.234)$; it does so negatively with Household Income $(r=-0.326)$, Number of Children $(r=-0.140)$, Job Category $(r=-0.189)$, Tenure $(r$ $=-0.258)$, and Self-employment $(r=-0.141)$. In women, Job Insecurity statistically significantly and positively correlates with Temporary Work $(r=0.363)$, Informal Work $(r=0.097)$, Job Category $(r=0-0.124)$, and Salary Cut $(r=0.193)$; it does so negatively with Household Income $(r=-0.181)$, Tenure $(r=$ $-0.297)$, and Self-employment $(r=-0.087)$. In general, all the variables correlate in the same direction with Job Insecurity in men and women, except Education, which does so positively in men and negatively in women. Job Insecurity and Age do not 
TABLE 3 | Correlations between Job Insecurity and the socio-economic and labor variables in men and women.

\begin{tabular}{|c|c|c|c|c|c|c|c|c|c|c|c|c|}
\hline & 1. & 2. & 3. & 4. & 5. & 6. & 7. & 8. & 9. & 10. & 11. & 12. \\
\hline 1.Job insecurity & 1 & -0.089 & $-0.326^{\star \star}$ & $-0.140^{\star \star}$ & $0.115^{\star}$ & $-0.258^{\star \star}$ & $0.329^{\star \star}$ & 0.086 & 0.052 & $-0.189^{\star \star}$ & $-0.141^{\star \star}$ & $0.234^{\star *}$ \\
\hline 2.Age & -0.017 & 1 & 0.070 & $0.377^{\star \star}$ & 0.005 & $0.714^{\star *}$ & $-0.432^{\star \star}$ & 0.016 & $-0.307^{\star \star}$ & 0.061 & $0.142^{\star *}$ & $0.110^{*}$ \\
\hline 3.Income & $-0.181^{\star \star}$ & -0.008 & 1 & 0.065 & $0.112^{*}$ & $0.194^{* *}$ & $-0.149^{\star \star}$ & -0.014 & -0.057 & $0.111^{*}$ & $0.146^{\star *}$ & -0.058 \\
\hline 4.N. of children & -0.018 & $0.318^{\star \star}$ & -0.047 & 1 & 0.027 & $0.253^{\star \star}$ & $-0.243^{\star \star}$ & -0.019 & $-0.139^{\star \star}$ & 0.002 & $0.148^{\star \star}$ & 0.055 \\
\hline 5.Education & -0.020 & -0.023 & $0.165^{\star *}$ & -0.022 & 1 & 0.030 & 0.061 & 0.048 & -0.042 & $0.123^{\star}$ & -0.070 & 0.002 \\
\hline 8.Informal work & $0.097^{\star}$ & 0.075 & -0.039 & $0.087^{\star}$ & $0.120^{*}$ & -0.022 & $-0.286^{\star \star}$ & 1 & $-0.100^{\star}$ & 0.009 & $-0.379^{\star *}$ & $-0.105^{\star}$ \\
\hline 9.Part-time W. & 0.075 & $-0.247^{\star \star}$ & -0.053 & $-0.155^{\star \star}$ & -0.072 & $-0.236^{\star \star}$ & $0.228^{\star \star}$ & $-0.191^{\star \star}$ & 1 & -0.025 & -0.037 & -0.002 \\
\hline 10.Job category & $-0.124^{\star *}$ & $-0.159^{\star \star}$ & $0.179^{\star *}$ & $-0.094^{\star}$ & $0.150^{\star \star}$ & $0.122^{\star \star}$ & $-0.165^{\star \star}$ & $0.109^{\star \star}$ & $-0.163^{\star \star}$ & 1 & $0.101^{*}$ & -0.050 \\
\hline 11.Self-emp. & $-0.087^{\star}$ & $0.176^{\star \star}$ & 0.046 & 0.014 & -0.003 & $0.170^{\star \star}$ & -0.031 & $-0.310^{\star \star}$ & $-0.082^{\star}$ & 0.063 & 1 & 0.018 \\
\hline 12.Salary cut & $0.193^{\star *}$ & $0.115^{\star \star}$ & $-0.134^{\star \star}$ & 0.074 & $-0.085^{\star}$ & -0.045 & $0.115^{\star \star}$ & -0.021 & $0.093^{\star}$ & $-0.110^{\star \star}$ & $0.106^{\star}$ & 1 \\
\hline
\end{tabular}

Men above the diagonal; Women below the diagonal; ${ }^{\star} P<0.05$; ${ }^{\star \star} P<0.01$; Confidence interval: $95 \%$.

TABLE 4 | Results of multiple linear regression analysis of predictors associated with job insecurity in men and women (standardized coefficients).

\begin{tabular}{|c|c|c|c|c|}
\hline \multirow[b]{2}{*}{ Predictors } & \multicolumn{2}{|c|}{ Men } & \multicolumn{2}{|c|}{ Women } \\
\hline & $\beta$ & $\Delta \mathrm{R}^{2}$ & $\beta$ & $\Delta R^{2}$ \\
\hline Temporary work & $0.314^{\star \star}$ & $0.108^{\star \star}$ & $0.361^{\star \star}$ & $0.132^{\star *}$ \\
\hline Informal work & $0.204^{\star \star}$ & $0.43^{\star \star}$ & $0.181^{\star \star}$ & $0.044^{\star \star}$ \\
\hline Salary cut & $0.220^{\star \star}$ & $0.039^{\star \star}$ & $0.119^{\star \star}$ & $0.022^{\star \star}$ \\
\hline Househols income & $-0.263^{\star \star}$ & $0.078^{\star \star}$ & - & - \\
\hline Education & $0.132^{\star \star}$ & $0.017^{\star \star}$ & - & - \\
\hline Job category & $-137^{\star \star}$ & $0.014^{\star \star}$ & - & - \\
\hline Tenure & - & - & $-0.239^{\star \star}$ & $0.010^{\star}$ \\
\hline Number of children & - & - & - & - \\
\hline Part-time work & - & - & - & - \\
\hline Self-employment & - & - & - & - \\
\hline$R^{2}$ adjusted & \multicolumn{2}{|c|}{$0.287^{\star \star \star}$} & \multicolumn{2}{|c|}{$0.230^{\star \star}$} \\
\hline
\end{tabular}

$\beta$, Standardized coefficient; $R^{2}$ adjusted, Adjusted percentage of variance explained; $\Delta R^{2}$, Change in percentage of variance explained; ${ }^{*} P<0.05$; ${ }^{* *} P<0.01$; Confidence interval: $95 \%$.

correlate in any of the groups. Therefore, the variable Age was not included in the regression analysis.

The results of the linear regression can be seen in Table 4. For the sample of men, the model obtained includes the following predictor variables, in order of importance in the model: Temporary Work $(\beta=0.314)$, Household Income $(\beta=-0.258)$, Salary Cut $(\beta=0.263)$, Informal Work $(\beta=0.204)$, Education $(\beta=0.132)$, and Job Category $(\beta=-0.137)$. For the sample of women, the resulting model contains the variables, Salary cut ( $\beta=0.119)$, Temporary Work $(\beta=0.361)$, Informal Work $(\beta$ $=0.181)$, and Tenure $(\beta=-0.293)$. Number of Children, Parttime work, and Self-employment were not statistically significant variables in any of the samples, so they do not predictor Job Insecurity. The model explains $28.7 \%$ of variance in men and $23 \%$ in women.

\section{DISCUSSION}

The objective of this study is to determine the existing gender differences when predicting perceived job insecurity based on individual and organizational objective variables. Previous studies took gender as a job insecurity predictor $(22,37,48)$ but this article, compared the results in men and women to study the influence of the social and cultural context on job insecurity. Generally speaking, it has been found that differences in men and women with respect to the development of job insecurity reflect gender inequality at work. Women showed a higher score in job insecurity than men, taking a general measure and without controlling the influence of other variables. So, Hypothesis 1 (There is no difference between the general score for job insecurity in men and women) was not confirmed. Regarding Hypothesis 2, (Job insecurity increases in a more vulnerable socio-economic context, such as (a) lower household income, (b) having children, and (c) a lower level of education) was not satisfied, as a higher level of Job Insecurity was observed in men workers with university studies. Finally, Hypotheses 3 (The level of job insecurity increases in the case of being in a weak labor position, such as (a) informal work, (b) temporary contracts, (c) part-time work, and (d) having suffered a change in the contract in the last year), and Hypothesis 4 (H4: In a stronger labor position, such as (a) a longer tenure and (b) a white collar job category, the job insecurity decreases) were corroborated, but differently in men and women, because there are some elements that appear in both genders, but others only in one of the groups.

If we look at the common variables, we find some related to working conditions. The results obtained point to temporary work, informal work and salary cuts in the last year as predictors in both groups. These are variables associated with a weak labor market position (67) that had previously been defined as predictors of job insecurity (9). The fact that organizational changes generate greater fear of losing one's job becomes especially important $(22,68)$, as having experienced a cut in salary in the last year. 
If we consider the specific conditions or variables that present differences between the models obtained, we find the following: household income level, education and job category are statistically significant in the group of men, but not so in the group of women. The opposite occurs with tenure, which, in our results, only appears in the female sample model. Regarding income, the discrepancies in this variable are explained by maintaining the model that understands the man as the main breadwinner (Lewis, 2001), since, when the men belong to a household with low income, the fear of losing their job increases. Thus, although both men and women work in the family unit, the female salary is still assumed today as secondary and complementary to the male partner, as Giesselman (69) observed in European countries such as Germany. The results referring to the influence of education reflect a changing reality: they show that job insecurity also grows at higher educational and professional levels in the men sample. This phenomenon is being observed among general youth $(54,55)$, and may be playing an important role in unfulfilled labor expectations. Its relevance in the group of men and not in that of women could be related to their tendency to focus more on their professional careers, while women are forced to divide their attention between work and family (42). Moreover, this is one of the factors that generates occupational segregation, especially the so-called glass ceiling (27). The relation is inverse with the job category, increasing the job insecurity among the blue collar workers, in the line of previous studies (9).

On the other hand, despite seniority in the company being related to insecurity, in this study we can observe that the threat of the loss is more relevant in women when they have not held the job for a long time. A possible explanation would be the expectations related to the presence of higher figures of precariousness for female work $(25,42)$, which could be increasing women's fear of being fired or not having their contracts renewed. Authors such as Lübke and Erlinghagen (21) sustained that greater seniority in the company decreases job insecurity, and our results extend this idea with the gender perspective. However, seniority in the company is a variable that is highly related to age and the identity that the job grants to people $(46,70,71)$. Regarding age, the results do not support the existence of a linear relationship between age and job insecurity in any group, as Glavin and Young (51) found. Even so, studies that focus on specific age groups, such as youth or over- $45 \mathrm{~s}$, would be necessary in the job insecurity field of study. We must emphasize that labor relations in the framework of neoliberalism do not follow the linear path characteristic of Fordism $(5,72)$. Therefore, the variables age and seniority at the company do not maintain the same relationship with job insecurity.

In short, it is observed that the variables of success and professional career (job category, household income), maintained and reproduced by traditional roles, become more important in men. In contrast, women are conditioned by the highly discriminatory and segregating labor environment that often submits them to higher percentages of working poverty, part-time work, discrimination, lower salaries, etc. (25). These circumstances determine the expectations of both genders, so perceived job insecurity also varies. This goes to show and reflects that real equality at work has still not been achieved; but outside it has not been either. Women's lives are conditioned by their dual presence in two type of jobs: both in paid jobs and in the work required to care for and maintain the household $(25,27)$. The need for an in-depth social change regarding gender roles continues to exist, that will equal the conditions of men and women both in the labor environment and in life courses. Meanwhile, parity and equilibrium measures of these inequality contexts help to take further steps in that direction, such as the implementation of efficient equality, non-discrimination and conciliation policies for both genders (73).

\section{PRACTICAL IMPLICATIONS}

These results were obtained in the context of the Spanish labor market, which is defined by a flexible neoliberal model, and with unemployment, temporary and poor worker rates above the European average, especially in women $(55,72)$. This complements other research on countries with similar labor models and provides knowledge about the effects of job insecurity in these contexts. Otherwise, the research show the need to conduct more gender-sensitive studies. It is a strategy that does more than just include the variable in the analysis, as it requires considering the background, relations and consequences that a social and cultural context of gender inequality has on the phenomenon studied. In this way it will be possible to understand questions not solved in scientific literature or increase knowledge to propose and reach more efficient solutions that adapt to today's social reality. In agreement with the results obtained, it is important to maintain this vision, as well as to resume and copy studies conducted by other authors, bearing in mind the influence of gender.

On the other hand, the psychological approach used to address topics such as the one we present here also has implications. In our study, the gender differences found in the development of job insecurity were proposed from a psychosocial approach, not giving priority to intrapsychic variables. The results support the fact that anticipating the loss of a job is not only explained by this type of individual factors, and that the variables relating to the environment are also relevant (46). Thus, they show that today's labor context, marked by instability, leads people to develop a perception of insecurity, placing its origin at levels above individual psychological differences. This means that the responsibility for the appearance of discontent associated with work does not correspond to the individual, but to the precarious conditions. Otherwise, this is a phenomenon that cannot only be tackled by interventions with the workers, but rather, a holistic approach is required that considers both the individual level (repairing), and the social level (organization and contextual). With all of this, and given the deterioration that job insecurity generates in workers $(12,13,74)$, its prevention must be a necessary and urgent question. Resuming the Keynesian work model is not 
possible, but putting political, legal, economic initiatives, etc. into motion are essential, to guarantee greater stability in job careers, especially in women. Its objective would be to compensate the environment of flexibility and mobility that characterizes the current labor market and that favors discontent in workers.

\section{LIMITATIONS AND FUTURE RESEARCH}

This research, however, presents certain limitations. There are three analysis variables that have not been significant in the model, contrary to what is expected: part-time work, number of children and self-employment. Working part time has been defined as a predictor of job insecurity by other authors (9). In the future, a more complete measure of this variable is recommended, especially due to its high presence in female paid work (29). Regarding having children and the number of them, Näswall and De Witte (48) and Richter, Näswall and Sverke (35) did not find any relationship with job insecurity, neither. Even so, the possibility of analyzing whether this variable is relevant faced with the fear of losing one's job in other more specific population profiles, such as women with different family and socioeconomic situations, for example, single mothers, is put forward. Finally, self-employed work has been introduced, not having considered it as a predictor of job insecurity in previous studies. Even so, it is necessary to develop job insecurity studies in self-employed workers, a vulnerable group insofar as social and economic conditions are concerned $(61,75)$. We also recommend delving into the new relationships observed between job insecurity and educational level, especially among young people, and with generational studies.

\section{REFERENCES}

1. Greenhalgh L, Rosenblatt Z. Job insecurity: toward conceptual clarity. Acad Manage Rev. (1984) 9:438-48. doi: 10.2307/258284

2. Davy JA, Kinicki AJ, Scheck CL. A test of job security's direct and mediated effects on withdrawal cognitions. J Organ Behav. (1997) 18:323-49. doi: 10. 1002/(SICI)1099-1379(199707)18:4<323::AID-JOB801>3.0.CO;2-\%23

3. Vander Elst T, De Witte H, De Cuyper N. The job insecurity scale: a psychometric evaluation across five European countries. Eur J Work Organ Psychol. (2014) 23:364-80. doi: 10.1080/1359432X.2012.745989

4. Bauman Z. Liquid Modernity. Cambridge: Polity Press (2000).

5. Alonso LE. Trabajo y posmodernidad, El empleo débil. Madrid: Fundamentos (2000).

6. Burchell B, Sehnbruch K, Piasna A, Agloni N. The quality of employment and decent work: definitions, methodologies, and ongoing debates. Camb J Econ. (2014) 38:459-77. doi: 10.1093/cje/bet067

7. Nielsen KJ, Kines P, Pedersen LM, Andersen LP, Andersen DR. A multi-case study of the implementation of an integrated approach to safety in small enterprises. Saf Sci. (2015) 71:142-50. doi: 10.1016/j.ssci.2013.11.015

8. Beck U. Risk Society: Towards a New Modernity. London: SAGE Publications (1992).

9. Shoss MK. Job insecurity: an integrative review and agenda for future research. J Manag. (2017) 43:1911-39. doi: 10.1177/0149206317691574

10. Llosa JA, Menéndez-Espina S, Agulló-Tomás E, Rodríguez-Suárez J, BoadaGrau J. Spanish validation of the job jnsecurity scale JIS-8: viability of the cognitive and affective model. Psicothema. (2017) 29:577-83. doi: $10.7334 /$ psicothema2017.59

\section{CONCLUSIONS}

The main contribution of this study with respect to knowledge about job insecurity refers to the differences found in men and women. In general, this perception appears under clearly differentiated conditions that respond to gender inequality at work $(25,42)$. In conclusion, although scientific literature determines that job insecurity is developed in the same way in men and women, in quantitative terms, differences of a different nature have been found that lead to a more in-depth knowledge of the background of this phenomenon and its implications.

\section{DATA AVAILABILITY STATEMENT}

The datasets generated for this study are available on request to the corresponding author.

\section{ETHICS STATEMENT}

The studies involving human participants were reviewed and approved by Ethics Committee of Oviedo University. The patients/participants provided their written informed consent to participate in this study.

\section{AUTHOR CONTRIBUTIONS}

SM-E, JL, and EA-T: conception and design of the work. HL-D and RS-V: data collection. SM-E, JL, and JB-G: data analysis and interpretation. SM, JL, and JR-S: drafting the article. HD, EA-T, and JR-S: critical revision of the manuscript. All authors read and approved the final version of the manuscript.

11. Sverke M, Hellgren J, Näswall K. No security: a meta-analysis and review of job insecurity and its consequences. J Occup Health Psychol. (2002) 7:242-64. doi: 10.1037//1076-8998.7.3.242

12. De Witte H, Pienaar J, De Cuyper N. Review of 30 years of longitudinal studies on the association between job insecurity and health and well-being: is there causal evidence? Aust Psychol. (2016) 51:18-31. doi: 10.1111/ap. 12176

13. Cheng G, Chan D. Who suffers more from job insecurity? A meta-analytic review. Appl Psychol. (2008) 57:272-303. doi: 10.1111/j.1464-0597.2007.00312.x

14. Blom V, Richter A, Hallsten L, Svedberg P. The associations between job insecurity, depressive symptoms and burnout: the role of performance-based self-esteem. Econ Ind Democr. (2015) 39:48-63. doi: $10.1177 / 0143831 X 15609118$

15. Boya FO, Demiral Y, Ergor A, Akvardar Y, De Witte H. Effects of perceived job insecurity on perceived anxiety and depression in nurses. Ind Health. (2008) 46:613-9. doi: 10.2486/indhealth.46.613

16. Kim M-S, Hong Y-C, Yook J-H, Kang M-Y. Effects of perceived job insecurity on depression, suicide ideation, and decline in self-rated health in Korea: a population-based panel study. Int Arch Occup Environ Health. (2017) 90:663-71. doi: 10.1007/s00420-017-1229-8

17. Henseke G. Good jobs, good pay, better health? The effects of job quality on health among older European workers. Eur J Health Econ. (2018) 19:59-73. doi: 10.1007/s10198-017-0867-9

18. Schnall PL, Dobson M, Landsbergis P. Globalization, work, and cardiovascular disease. Int $J$ Health Serv. (2016) 46:656-92. doi: $10.1177 / 0020731416664687$ 
19. Virtanen M, Nyberg ST, Batty GD, Jokela M, Heikkila K, Fransson EI, et al. Perceived job insecurity as a risk factor for incident coronary heart disease: systematic review and meta-analysis. BMJ. (2013) 347:f4746. doi: 10.1136/bmj.f4746

20. Schaufeli WB. Job insecurity research is still alive and kicking twenty years later: a commentary. Aust Psychol. (2016) 51:32-5. doi: 10.1111/ap.12201

21. Lübke C, Erlinghagen M. Self-perceived job insecurity across Europe over time: does changing context matter? J Eur Soc Policy. (2014) 24:319-36. doi: $10.1177 / 0958928714538215$

22. Keim AC, Landis RS, Pierce CA, Earnest DR. Why do employees worry about their jobs? A meta-analytic review of predictors of job insecurity. J Occup Health Psychol. (2014) 19:269-90. doi: 10.1037/a0036743

23. Probst TM, Lavaysse M. Job insecurity: implications for employee well-being. In: Burke RJ, Page KM, editors. Research Handbook on Work and Well-Being. Cheltenham: Edward Elgar Publishing (2017). p. 123-49.

24. Betti E. Gender and precarious labor in a historical perspective: Italian women and precarious work between fordism and post-fordism. Int Labor Work-Cl Hist. (2016) 89:64-83. doi: 10.1017/S0147547915000356

25. ILO. Women at Work: Trends 2016. Geneva: International Labour Organization (2016). Available online at: http://www.ilo.org/gender/ Informationresources/Publications/WCMS_457317/lang--en/index.htm (accessed February 19, 2018).

26. Buonocore F, Russo M, Ferrara M. Work-family conflict and job insecurity: are workers from different generations experiencing true differences? Community Work Fam. (2015) 18:299-316. doi: 10.1080/13668803.2014.981504

27. Burchell B, Hardy V, Rubery J, Smith M. A New Method to Understand Occupational Gender Segregation in European Labour Markets. Belgium: European Commission-Directorate-General for Justice (2014). Available online at: https://ec.europa.eu/info/files/new-method-understandoccupational-gender-segregation-european-labour-markets-2015_en (accessed November 15, 2019).

28. Fox AB, Quinn DM. Pregnant women at work: the role of stigma in predicting women's intended exit from the workforce. Psychol Women Q. (2015) 39:22642. doi: 10.1177/0361684314552653

29. Lyonette C. Part-time work, work-life balance and gender equality. J Soc Welf Fam Law. (2015) 37:321-33. doi: 10.1080/09649069.2015.1081225

30. Giron A, Correa E. Post-crisis gender gaps: women workers and employment precariousness. J Econ Issues. (2016) 50:471-7. doi: 10.1080/00213624.2016.1179049

31. Worth $\mathrm{N}$. Who we are at work: millennial women, everyday inequalities and insecure work. Gend Place Cult. (2016) 23:1302-14. doi: 10.1080/0966369X.2016.1160037

32. Charles $\mathrm{N}$, James $\mathrm{E}$. The gender dimensions of job insecurity in a local labour market. Work Employ Soc. (2003) 17:531-52. doi: 10.1177/09500170030173007

33. Gaunt R, Benjamin O. Job insecurity, stress and gender. Community Work Fam. (2007) 10:341-55. doi: 10.1080/13668800701456336

34. Näswall K, Lindfors P, Sverke M. Job insecurity as a predictor of physiological indicators of health in healthy working women: an extension of previous research. Stress Health. (2012) 28:255-63. doi: 10.1002/smi.1430

35. Richter A, Näswall K, Sverke M. Job insecurity and its relation to work-family conflict: mediation with a longitudinal data set. Econ Ind Democr. (2010) 31:265-80. doi: 10.1177/0143831X09358370

36. Rigotti T, Mohr G, Isaksson K. Job insecurity among temporary workers: looking through the gender lens. Econ Ind Democr. (2015) 36:523-47. doi: 10.1177/0143831X13516026

37. Kinnunen U, Mauno S, Natti J, Happonen M. Perceived job insecurity: a longitudinal study among finnish employees. Eur J Work Organ Psychol. (1999) 8:243-60. doi: 10.1080/135943299398348

38. Lewis J. The decline of the male breadwinner model: implications for work and care. Soc Polit Int Stud Gend State Soc. (2001) 8:152-69. doi: $10.1093 / \mathrm{sp} / 8.2 .152$

39. De Witte H. Job insecurity and psychological well-being: review of the literature and exploration of some unresolved issues. Eur J Work Organ Psychol. (1999) 8:155-77. doi: 10.1080/135943299398302

40. Campos-Serna J, Ronda-Pérez E, Artazcoz L, Moen BE, Benavides FG. Gender inequalities in occupational health related to the unequal distribution of working and employment conditions: a systematic review. Int J Equity Health (2013) 12:57. doi: 10.1186/1475-9276-12-57

41. Emberland JS, Rundmo T. Implications of job insecurity perceptions and job insecurity responses for psychological well-being, turnover intentions and reported risk behavior. Saf Sci. (2010) 48:452-9. doi: 10.1016/j.ssci.2009.12.002

42. Alcañiz M, Monteiro R. She-austerity. Women's precariousness and labor inequality in Southern Europe. Converg-Rev Cienc Soc. (2016) 23:39-67. doi: 10.29101/crcs.v0i72.4089

43. Bethge M, Radoschewski FM, Mueller-Fahrnow W. Job insecurity as risk for adverse health effects amongst german workers: a cohort study. Gesundheitswesen. (2008) 70:381-6. doi: 10.1055/s-00281082078

44. Berntson E, Näswall K, Sverke M. The moderating role of employability in the association between job insecurity and exit, voice, loyalty and neglect. Econ Ind Democr. (2010) 31:215-30. doi: 10.1177/0143831X09358374

45. Comisión Europea. Manual: el género en la investigación. Luxembourg: Publications Office of the European Union (2011). Available online at: http:// www.idi.mineco.gob.es/stfls/MICINN/Investigacion/FICHEROS/El_genero_ en_la_investigacion.pdf (accessed April 2, 2018).

46. Lee C, Huang G-H, Ashford SJ. Job insecurity and the changing workplace: recent developments and the future trends in job insecurity research. Annu Rev Organ Psychol Organ Behav. (2018) 5:335-59. doi: 10.1146/annurev-orgpsych-032117-104651

47. Muñoz de Bustillo R, de Pedraza P. Determinants of job insecurity in five European countries. Eur J Ind Relat. (2010) 16:5-20. doi: 10.1177/0959680109355306

48. Näswall K, De Witte H. Who feels insecure in Europe? Predicting job insecurity from background variables. Econ Ind Democr. (2003) 24:189-215. doi: 10.1177/0143831X03024002003

49. Kinnunen U, Makikangas A, Mauno S, De Cuyper N, De Witte H. Development of perceived job insecurity across two years: associations with antecedents and employee outcomes. J Occup Health Psychol. (2014) 19:24358. doi: 10.1037/a0035835

50. Urbanaviciute I, Udayar S, Maggiori C, Rossier J. Precariousness profile and career adaptability as determinants of job insecurity: a three-wave study. $J$ Career Dev. (2018) 47:146-61. doi: 10.1177/0894845318791777

51. Glavin P, Young M. Insecure people in insecure places: the influence of regional unemployment on workers' reactions to the threat of job loss. J Health Soc Behav. (2017) 58:232-51. doi: 10.1177/0022146517696148

52. Fullerton AS, Wallace M. Traversing the flexible turn: US workers' perceptions of job security, 1977-2002. Soc Sci Res. (2007) 36:201-21. doi: 10.1016/j.ssresearch.2005.09.005

53. Moore S, Grunberg L, Greenberg E. Repeated downsizing contact: the effects of similar and dissimilar layoff experiences on work and well-being outcomes. J Occup Health Psychol. (2004) 9:247-57. doi: 10.1037/1076-8998.9.3.247

54. Helbling L, Kanji S. Job insecurity: differential effects of subjective and objective measures on life satisfaction trajectories of workers aged 27-30 in Germany. Soc Indic Res. (2018) 137:1145-62. doi: 10.1007/s11205-0171635-Z

55. Lasheras-Díez HF, Menéndez-Espina S, Llosa JA, Rodríguez-Suárez J, AgullóTomás E, Sáiz-Villar R. Nuevos retos laborales en los jóvenes trabajadores: formación académica e incertidumbre laboral en menores de 30 años. Encruc-Rev Crítica Cienc Soc. (2018) 15:a1501.

56. Kinnunen U, Mauno S, Siltaloppi M. Job insecurity, recovery and wellbeing at work: recovery experiences as moderators. Econ Ind Democr. (2011) 31:179-94. doi: 10.1177/0143831X09358366

57. Mauno S, Kinnunen U. Perceived job insecurity among dual-earner couples: Do its antecedents vary according to gender, economic sector and the measure used? J Occup Organ Psychol. (2002) 75:295-314. doi: 10.1348/096317902320369721

58. Parker SK, Griffin MA, Sprigg CA, Wall TD. Effect of temporary contracts on perceived work characteristics and job strain: a longitudinal study. Pers Psychol. (2002) 55:689-719. doi: 10.1111/j.1744-6570.2002.tb00126.x

59. Debus ME, Koenig CJ, Kleinmann M. The building blocks of job insecurity: the impact of environmental and person-related variables on job insecurity perceptions. J Occup Organ Psychol. (2014) 87:329-351. doi: 10.1111 /joop. 12049 
60. Anderson CJ, Pontusson J. Workers, worries and welfare states: social protection and job insecurity in 15 OECD countries. Eur J Polit Res. (2007) 46:211-35. doi: 10.1111/j.1475-6765.2007.00692.x

61. Schonfeld IS, Mazzola JJ. A qualitative study of stress in individuals selfemployed in solo businesses. J Occup Health Psychol. (2015) 20:501-13. doi: $10.1037 / \mathrm{a} 0038804$

62. Kalleberg AL. Precarious work, insecure workers: employment relations in transition. Am Sociol Rev. (2009) 74:1-22. doi: 10.1177/000312240907400101

63. Giatti L, Barreto SM, César CC. Household context and self-rated health: the effect of unemployment and informal work. J Epidemiol Community Health. (2008) 62:1079-85. doi: 10.1136/jech.2007.069740

64. Pienaar J, De Witte H, Hellgren J, Sverke M. The cognitive/affective distinction of job insecurity: validation and differential relations. South Afr Bus Rev. (2013) 17:1-22.

65. Cohen J, Cohen P, West SG, Aiken LS. Applied Multiple Regression/Correlation for the Behavioral Sciences. 3rd ed. Mahwah, NJ: Erlbaum (2003).

66. APA. Ethical Principles of Psychologists and Code of Conduct. (2017). Washington, DC: APA. Available online at: http://www.apa.org/ethics/code/ (accessed December 26, 2019).

67. Benach J, Vives A, Amable M, Vanroelen C, Tarafa G, Muntaner C. Precarious employment: understanding an emerging social determinant of health. Annu Rev Public Health. (2014) 35:229-53. doi: 10.1146/annurev-publhealth-032013-182500

68. Nikolova I, van Dam K, Van Ruysseveldt J, De Witte H. Feeling weary? Feeling insecure? Are all workplace changes bad news? Int J Environ Res Public Health. (2019) 16:1842. doi: 10.3390/ijerph16101842

69. Giesselmann M. Differences in the patterns of in-work poverty in Germany and the UK. Eur Soc. (2015) 17:27-46. doi: 10.1080/14616696.2014.968796

70. Agulló-Tomás E. La centralidad del trabajo en el proceso de construcción de la identidad de los jóvenes: una aproximación psicosocial. Psicothema. (1998) 10:153-65.
71. Selenko E, Mäkikangas A, Stride CB. Does job insecurity threaten who you are? Introducing a social identity perspective to explain well-being and performance consequences of job insecurity. J Organ Behav. (2017) 38:856-75. doi: $10.1002 /$ job. 2172

72. Agulló-Tomás E, Llosa JA, Agulló-Tomás MS. Trabajo indecente, contexto actual e implicaciones. In: La interacción Social (Homenaje a José Ramón Torregrosa). Madrid: Centro de Investigaciones Sociológicas (CIS) Academia.

73. ILO. ABC of Women Workers' Rights and Gender Equality. (2007). Available online at: https://www.ilo.org/wcmsp5/groups/public/---dgreports/--gender/documents/publication/wcms_087314.pdf (accessed June 16, 2020).

74. Llosa JA, Menéndez-Espina S, Agulló-Tomás E, Rodríguez-Suárez J. Job insecurity and mental health: a meta-analytical review of the consequences of precarious work in clinical disorders. Anal Psicol. (2018) 34:211-21. doi: 10.6018/analesps.34.2.281651

75. Halleröd B, Ekbrand H, Bengtsson M. In-work poverty and labour market trajectories: poverty risks among the working population in 22 European countries. J Eur Soc Policy. (2015) 25:473-88. doi: 10.1177/0958928715 608794

Conflict of Interest: The authors declare that the research was conducted in the absence of any commercial or financial relationships that could be construed as a potential conflict of interest.

Copyright (C) 2020 Menéndez-Espina, Llosa, Agulló-Tomás, Rodríguez-Suárez, SáizVillar, Lasheras-Diez, De Witte and Boada-Grau. This is an open-access article distributed under the terms of the Creative Commons Attribution License (CC BY). The use, distribution or reproduction in other forums is permitted, provided the original author(s) and the copyright owner(s) are credited and that the original publication in this journal is cited, in accordance with accepted academic practice. No use, distribution or reproduction is permitted which does not comply with these terms. 